\title{
IN VITRO BIOACTIVITY OF MICRO METAL INJECTION MOULDED STAINLESS STEEL WITH DEFINED SURFACE FEATURES
}

\author{
Malak Bitar ${ }^{1 *}$, Vera Friederici ${ }^{2}$, Philipp Imgrund ${ }^{2}$, Claudia Brose $^{1}$ and Arie Bruinink ${ }^{1}$ \\ ${ }^{1}$ Materials-Biology Interactions Lab, EMPA, Lerchenfelstrasse 5, CH-9014 St. Gallen, Switzerland \\ ${ }^{2}$ Fraunhofer Institute for Manufacturing and Advanced Materials (IFAM), Wiener Strasse 12, \\ 28359 Bremen, Germany
}

\begin{abstract}
Micrometre- and nanometre-scale surface structuring with ordered topography features may dramatically enhance orthopaedic implant integration. In this study we utilised a previously optimised micron metal injection moulding ( $\mu$-MIM) process to produce medical grade stainless steel surfaces bearing micrometre scale, protruding, hemispheres of controlled dimensions and spatial distribution. Additionally, the structured surfaces were characterised by the presence of submicrometre surface roughness resulting from metal grain boundary formation. Following cytocompatibility (cytotoxicity) evaluation using 3T3 mouse fibroblast cell line, the effect on primary human cell functionality was assessed focusing on cell attachment, shape and cytoskeleton conformation. In this respect, and by day 7 in culture, significant increase in focal adhesion size was associated with the microstructured surfaces compared to the planar control. The morphological conformation of the seeded cells, as revealed by fluorescence cytoskeleton labelling, also appeared to be guided in the vertical dimension between the hemisphere bodies. Quantitative evaluation of this guidance took place using live cytoplasm fluorescence labelling and image morphometry analysis utilising both, compactness and elongation shape descriptors. Significant increase in cell compactness was associated with the hemisphere arrays indicating collective increase in focused cell attachment to the hemisphere bodies across the entire cell population. Micrometre-scale hemisphere array patterns have therefore influenced cell attachment and conformation. Such influence may potentially aid in enhancing key cellular events such as, for example, neo-osteogenesis on implanted orthopaedic surfaces.
\end{abstract}

Keywords: Cell spreading; surface topography; progenitor cell; microstructure.

*Address for correspondence (current address):

Malak Bitar

Technical Research and Development

Novartis Pharma AG

CH-4057 Basel, Switzerland

Telephone Number: +41795926981

E-mail : malak.bitar@novartis.com

\section{Introduction}

In order to increase the clinical success of implanted devices, an optimal reaction must take place within the surrounding biological environment. For orthopaedic implants, such a reaction is defined by the rapid and enduring osteointegration.

Besides surface chemistry, a plethora of experimental data has highlighted the importance of the biomechanical conditions of substrate surfaces in modulating cell behaviour. Subsequently, it became evident that the presence of well-defined, $\mu \mathrm{m}$ - and nm-scale, surface variations significantly alters the recruited cell behaviour (Clark et al., 1987; Clark et al., 1990; Meyle et al., 1993; Liao et al., 2003; Hamilton et al., 2005; Dalby et al., 2007; Jäger et al., 2007). At the $\mu \mathrm{m}$-scale, ordered cues seem to simulate specific cell reactions such as cell migration and osteoblastic differentiation (Kaiser and Bruinink, 2004; Schneider et al., 2004; Bruinink et al., 2005). Spatially disordered $\mathrm{nm}$ scale surface features have also been shown to dramatically enhance osteoblastic differentiation (Dalby et al., 2007). Nanocues are known to regulate protein adsorption subsequently influencing the adhered cell conformation and behaviour (Webster et al., 2000; Liao et al., 2003; Born et al., 2009). Superimposed onto the clinical situation, surface topography has become an integral parameter in the design of orthopaedic implant surfaces as upon implantation; bioactive surface patterns may strongly enhance the recruitment of osteoprogenitor cells and their subsequent differentiation into mature and active osteoblasts (Schneider et al., 2004). Rapid contact osteogenesis at the implant interface ensures early stability and enhances the long term dynamic integration into the host (Davies, 2003).

Several $\mu \mathrm{m}$-scale, ordered, topographical patterns have therefore been investigated and in certain instances, the presence of these patterns was associated with considerable effects on cell functionality in vitro (Liao et al., 2003; Hamilton et al., 2006; Zhao et al., 2006; Hamilton and Brunette, 2007; Hamilton et al., 2007; Kirmizidis and Birch, 2009). The precise mechanisms by which surface topography influences cell functionality are still poorly understood. However, it is thought that ordered topographical cues influence mediators of cell-substrate interaction such as focal adhesion (FA) complexes and the actin cytoskeleton. Consequently, and as these "mechanoconductive" elements directly regulate intracellular signalling pathways, specific alterations to gene and protein expression occur as a function of substrate topography (Zamir and Geiger, 2001).

Various efforts within the material engineering field were utilised aiming at "translating" topographical 
features of well-defined shape, size and spatial distribution and of known bioactive potential onto implanted surfaces. For example, early attempts applied laser micromachining technology to create $\mu \mathrm{m}$-scale (7-19 $\mu \mathrm{m}$ in diameter), "pit" shaped, surface arrays on commercially pure titanium dental implants (Hallgren et al., 2003). Laser interference metallurgy was also successfully applied for $\mathrm{nm} / \mu \mathrm{m}$-scale, groove and ridge, surface patterning (Lasagni et al., 2007). More recently, electrochemical micromachining was used to produce bioactive multi-feature "microtopography" of titanium surfaces (Lu and Leng, 2005; Kern et al., 2007). To date, nonetheless, controlled microtopography structuring of metal implants remains hindered by technical limitations. The morphological parameters of topographical patterning are often strongly dictated by the "surfaceerosion" techniques employed; i.e., pits and grooves. Such methods, therefore, fall short in accommodating geometrically complex, protruding and evidently bioactive surface features. Additionally, the accuracy of replicated structures and the material structural properties may become compromised by the technique used (Hallgren et al., 2003; Lasagni et al., 2007). Moreover, and in the majority of cases, surface structuring takes place following implant production. Such a post-processing step often employs complex approaches resulting in increased cost and production time.

Recently, we reported on the optimisation of micron metal injection moulding ( $\mu$-MIM) aiming at faithfully replicating $\mu \mathrm{m}$ and sub- $\mu \mathrm{m}$ scale topographies onto metal implant surfaces (Imgrund et al., 2008; Felton et al., 2009; Haack et al., 2010). The $\mu$-MIM process involves the injection of a homogenous mix (feedstock) combining $\mu \mathrm{m}$-scale metal particles and organic binders into a mould cavity to replicate shapes and surfaces of choice. The moulded green part is sintered at high temperature whereby the final metal part is obtained as a result of metal particle fusion. The resulting surface exhibits the defined surface microtopography of the mould (with a degree of post-sintering volume reduction) and a defined, secondary, roughness resulting from grain boundary formation between the constituting metal particles (Imgrund et al., 2008). Such a one step production of controlled topographical patterning may potentially be incorporated within the implant manufacturing process i.e., no postprocessing would be required. Most importantly, the shape, size and distribution of such topographical features would only be limited by the mould design. We have successfully implemented this process to produce biomedical grade, high density, austenitic stainless steel metal surfaces using $\mu \mathrm{m}$ - and nm-scale metal particles.

This study describes previously unreported application of the $\mu$-MIM process to produce AISI 316L stainless steel parts characterised by $\mu \mathrm{m}$-scale surface arrays and the effects of such arrays on primary human bone marrow stromal cells (HBMC). The surface arrays are characterised by the presence of $\mu \mathrm{m}$ scale, equally spaced, hemispheres accurately copying the mould design. We have assessed two hemisphere size variants on cell behaviour compared to non-structured reference surface (NS). This took place by evaluating the attachment and three dimensional (3D) morphological conformation of human bone marrow stromal cells (HBMC). Our data showed significant changes in cell-substrate interaction patterns a result of surface topography possibly modulated by combined, multi featured, topography guidance. The findings presented in this study will be carried forward towards the one-step production of orthopaedic implants potentially capable, without additional functionalisation, of steering in vivo cell functionality.

\section{Materials and Methods}

\section{Micro metal injection moulding ( $\mu$-MIM)}

At this stage of the $\mu$-MIM technical development, stainless steel alloy (type AISI 316L) was chosen to produce the structured substrates. $316 \mathrm{~L}$ stainless steel is reported to support osteoblast adhesion, proliferation and differentiation (Puleo et al., 1991; Puleo and Bizios, 1992; Bordji et al., 1996) and commonly used in temporary orthopaedic devices such as fracture plates. In comparison to titanium implants, stainless steel permits less mineralised matrix formation in vivo (Oron et al., 2009). However, we focused in this study on showing the effect of surface micropatterning on cell behaviour. Ultimately, we aim at utilising the $\mu$-MIM process to produce and evaluate the osteogenic bioactivity of titanium alloy substrates.

A feedstock consisting of a master alloy (MA) powder (55\% chromium, $38 \%$ nickel and $7 \%$ molybdenum, particle size $5.8 \mu \mathrm{m}$ at d90; Sandvik Osprey, Neath, UK), carbonyl iron powder (particle size $5.8 \mu \mathrm{m}$ at D90; BASF, Ludwigshafen, Germany), micro carbonyl iron powder (particle size $2.0 \mu \mathrm{m}$ at d90; Dr. Fritsch, Fellbach, Germany) and nano iron powder (particle size $0.39 \mu \mathrm{m}$ at D90; American Elements, Los Angeles, CA, USA) and a wax/polyethylene based binder was prepared for the injection process. The binder consisted of $10 \%$ carnauba wax (Alfa Aesar, Ward Hill, MA, USA), $39 \%$ paraffin wax (Merck, Haar, Germany) and $50 \%$ of a backbone polymer LD polyethylene (Basell Polyolefine, Frankfurt, Germany), needed for the sufficient green part stability, and $1 \%$ of stearic acid (Merck) as surfactant. In the first series, samples were made varying the nanoparticle content of the feedstock from 0 to $33.3 \%$ (feedstock I: $0 \%$, II: $16.7 \%$, III: $25 \%$ and IV: $33.3 \%$ ). MA content was kept constant at $33.3 \%$. Carbonyl and micro carbonyl iron powders were blended at a $1: 1 \mathrm{w} / \mathrm{w}$ ratio and admixed to the MA and nano iron powder to make up the final powder composition. In the second series only feedstock I, composed of $33.3 \%$ MA powder and $67.7 \%$ carbonyl iron powder blend was used. For both series, the powder and binder components were premixed at $100{ }^{\circ} \mathrm{C}$ under an inert atmosphere (argon) and, subsequently, feedstock homogenisation took place using a sigma-blade kneader, at $120^{\circ} \mathrm{C}$, for $2 \mathrm{~h}$. Prior to the moulding procedure, the mould inserts were heated at $80^{\circ} \mathrm{C}$. To produce the moulded part, the feedstock was injected against the mould inserts using an HEK $30 \mathrm{KSA}$ piston moulding machine (MCP HEK, Lübeck, Germany) at $130{ }^{\circ} \mathrm{C}$. Structured samples were prepared using two nickel mould insert variants exhibiting concave hemispheres of 35 and $58 \mu \mathrm{m}$ in diameter and a centre-to-centre equidistance of 58 and $81 \mu \mathrm{m}$ respectively 

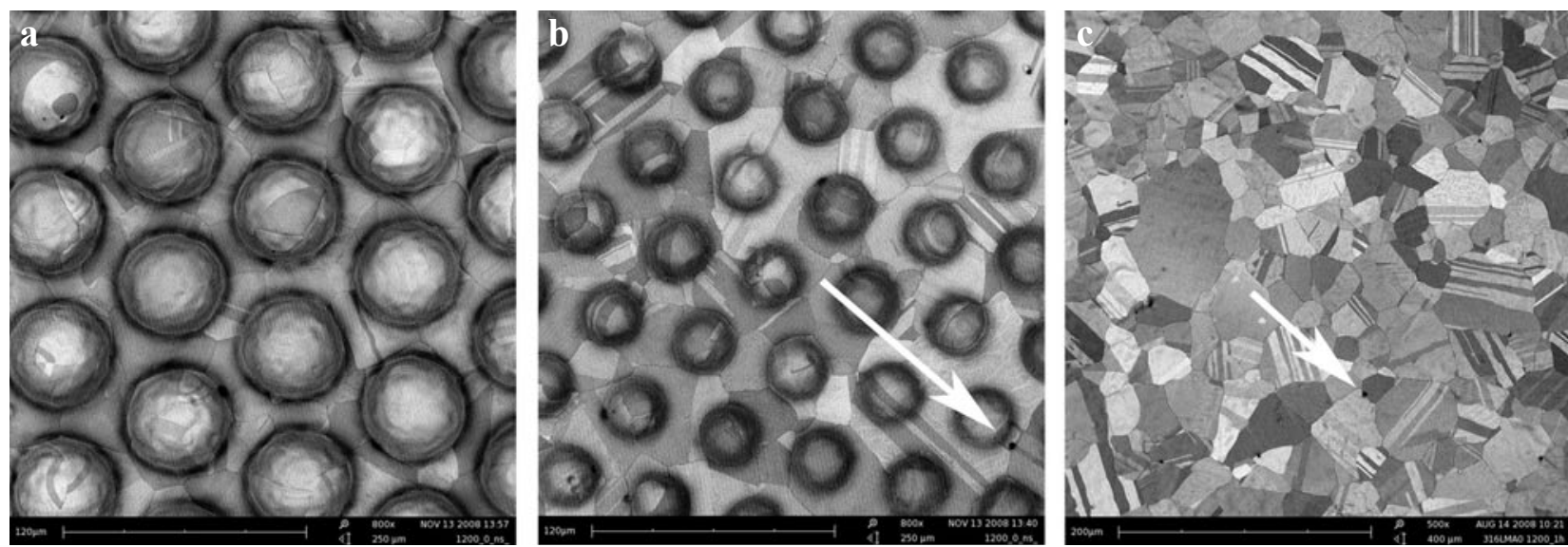

Fig. 1. Scanning electron micrographs of the biologically evaluated sintered 316L surfaces produced by $\mu$-MIM showing 50_20 (a), 30_20 (b), and NS (c). The stainless steel grain microstructure and grain boundaries are clearly visible. White arrow heads mark surface pits between the grains. (Work distance: $200 \mu \mathrm{m}$, no coating, EHT: $5 \mathrm{kV}$, Phenom Tabletop electron microscope).
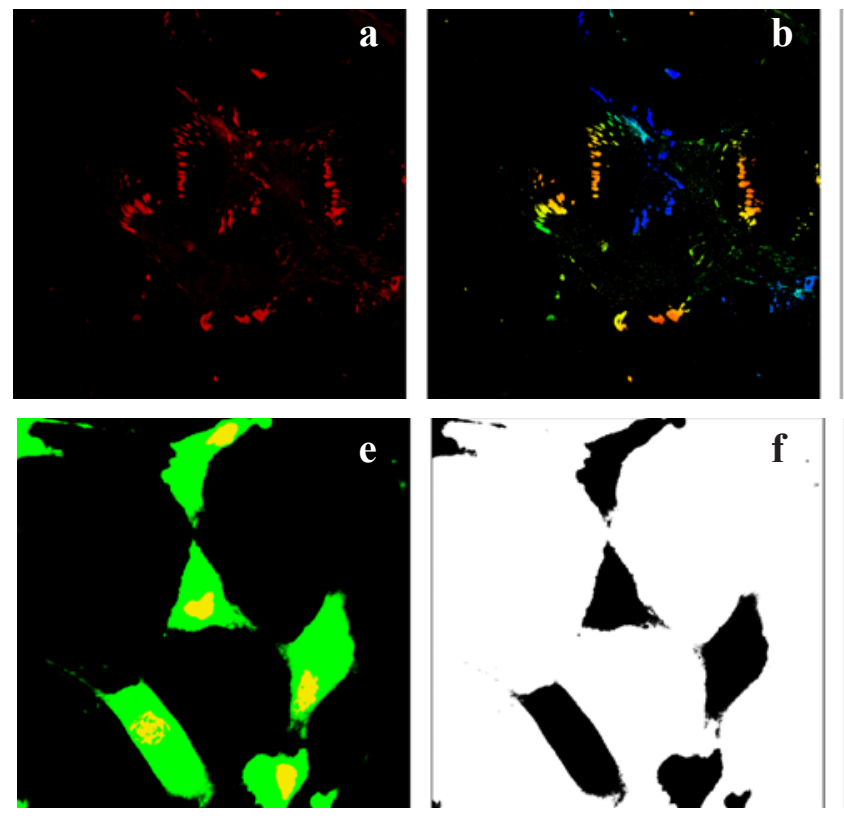

Fig. 2. Processing sequence of CLSM images using Image J software to evaluate vinculin labelled FAs (top row), and 2 dimensional cell shape descriptors of Calcein AM labelled cytoplasm (Bottom Row). (a) Vinculin labelled FAs as captured following CLSM acquisition; (b) Depth histogram application to facilitate adjacent FA's separation; (c) Image binary processing and watershed FA separation; (d) FA population within specific surface area range isolated and surface area measured for each FA; (e) Calcium/ DRAQ labelled cells as captured following CLSM acquisition; (f) Cell silhouettes binary images following threshold based isolation; (g) Automated exclusion of image boundary contacting cells from the analysis; (h) An example of the ellipse fitting process to establish cell elongation values.

(processing tolerance $\pm 3 \mu \mathrm{m}$ ). These measurements were calculated to reach 50 and $30 \mu \mathrm{m}$ diameter values (Fig. $1 \mathrm{~b}, \mathrm{c})$ termed 50_20 and 30_20 surfaces with a theoretical nearest equidistance of $20 \mu \mathrm{m}$ between the hemisphere bases, taking into account the sintering shrinkage. The final structured surface measured $25 \mathrm{~mm}^{2}$. A polished nickel plate was also used as mould insert against which, control non-structured surfaces (NS) were produced. After moulding, the wax constituents were extracted using hexane and thermal debinding. The resulting samples were sintered under hydrogen atmosphere in one furnace cycle with a constant heating rate of $10 \mathrm{~K}$ per min reaching a final temperature of $1200^{\circ} \mathrm{C}$ and an equivalent dwell time of $1 \mathrm{~h}$. Two series of samples were produced.

\section{Post-production material characterisation}

The sintered samples were evaluated for morphology and elemental content using energy dispersive X-ray spectroscopy (EDS) and scanning electron microscopy (SEM - Zeiss Gemini, Leo 1530, Oberkochen, Germany, equipped with INCA $10 \mathrm{~mm}^{2} \mathrm{Si}(\mathrm{Li})$ EDS detector, Oxford Instruments, Oxford, UK). EDS evaluation took place over a total scanned area of $10 \mathrm{~mm}^{2}$ for each sample. Relative density evaluation took place using the Archimedes 
method. Surface roughness evaluation was conducted by performing $3 \mathrm{D}$-surface scans with a white light profilometer (MicroProf, Fries Research \& Technology, Bergisch Gladbach, Germany) by scanning an area of $100 \times 100 \mu \mathrm{m}^{2}$. Thereafter, surface roughness values were calculated using the FRT Mark III (V. 3.8) software.

\section{Cell cultures}

3T3 Mouse Swiss Albino embryo fibroblasts were obtained from the European Collection of Cell Cultures, Salisbury, UK. Human bone marrow stromal cells (HBMC) were isolated from marrow tissue samples of patients undergoing total hip arthroplasty after informed consent (ethical approval EKSG 08/014). The donor patients were 3 males aged 49, 63 and 86 years and; 2 females aged 73 and 75 years. Following surgery, marrow tissue samples obtained from femoral head sections were suspended in isolation medium (25 mM HEPES, $128.5 \mathrm{mM} \mathrm{NaCl}, 5.4 \mathrm{mM} \mathrm{KCl}$, $5.5 \mathrm{mM} \mathrm{D}(+)$ glucose, $51.8 \mathrm{mM} \mathrm{D}(+)$ saccharose and $0.1 \%$ bovine serum albumin (BSA), pH 7.4 (Bruinink, 1992)) and centrifuged for $15 \mathrm{~min}$, at $800 \mathrm{rpm}$ and at $4{ }^{\circ} \mathrm{C}$. Following centrifugation, the supernatant containing most of the adipose and blood content was removed by aspiration. Subsequently, tissue samples were washed several times in isolation medium to flush-out the stromal cell population. The separated cell suspension was passed twice through a $200 \mu \mathrm{m}$ filter (PE mesh) and centrifuged for $15 \mathrm{~min}$, at 800 rpm and at $4{ }^{\circ} \mathrm{C}$. The resulting cell pellet was resuspended in proliferation medium consisting of alpha-minimum essential medium $(\alpha-\mathrm{MEM})$, supplemented with $10 \%$ foetal calf serum (FCS), $1 \%$ penicillin/ streptomycin (PSN. all from Invitrogen, Basel, Switzerland) in addition to $1 \mathrm{ng} /$ mL FGF-2 (Sigma-Aldrich, Buchs, Switzerland). HBMC cells were harvested before cultures reached confluence. Cell culture experiments took place in osteogenic medium consisting of $\alpha$-MEM with $10 \%$ FCS, $1 \%$ PSN, $10 \mathrm{nM}$ dexamethasone (dex), $50 \mu \mathrm{M}$ ascorbic acid phosphate (AA) and $2 \mathrm{mM} \beta$-glycerophosphate (BGP, dex, AA, and BGP were all from Sigma-Aldrich). Cells were seeded at $2.5 \times 10^{3} \mathrm{cell} / \mathrm{cm}^{2}$ and only cells of passage 1 were used. All experiments took place in a humidified atmosphere at $37{ }^{\circ} \mathrm{C}$ and $5 \% \mathrm{CO}_{2}$. Seeded samples were kept in $2 \mathrm{~cm}^{2}$ wells and a $1 \mathrm{~mL}$ medium was replaced at 2 day intervals.

\section{Cytocompatibility tests}

Cytocompatibility was determined by both evaluating the toxicity of sample extracts and the survival of cells seeded directly onto the structured surfaces. The cytocompatibility experiments performed in this study (i.e., acute toxicity, cell attachment and cell spreading) took place to ensure that the material properties such as degradation, oxidation and leaching did not adversely affect the seeded cell normal function.

\section{Cytotoxicity}

The potential release of toxic components by NS, and structured materials of feedstock I and IV was evaluated according to ISO10993-5 (2009) extract test using 3T3 fibroblasts. For this, material extracts were prepared according to ISO10993-12 (2009). For each variant (i.e., 30_20,50_20 and NS) and feedstock (feedstock I and IV only), 3 samples were incubated in carbonate buffered water ( $\mathrm{pH} 7.4$ ) for 3 days at $37^{\circ} \mathrm{C}$ under cell culture conditions. $5 x$ concentrated Dulbecco's modified eagle medium (DMEM) was added to the extracts and supplemented with $10 \%$ foetal calf serum (FCS) and $7.5 \%$ carbonate solution. Control extracts were prepared using control incubated carbonate buffered water only. 3T3 mouse fibroblasts were seeded into 96-well plates at a density of 1500 cells per well in $200 \mu \mathrm{L}$ medium. After $24 \mathrm{~h}$, the medium was replaced by the medium supplemented extracts. The cells were incubated for five days following which, total culture DNA, protein, MTT conversion and lysosomal neutral red accumulation were evaluated (Bruinink, 1992; Bruinink and Wintermantel, 2001).

To conduct the MTT assay, part of the culture medium was replaced by Serum starved DMEM containing $1 \mathrm{mg} /$ $\mathrm{mL}$ thiazolylblue tetrazolium bromide. Following $60 \mathrm{~min}$ incubation under cell culture conditions, the total culture medium was removed. Ethanol-HEPES solution $(100 \mu \mathrm{L})$ was added to each well for $15 \mathrm{~min}$ to dissolve the MTTformazan crystals. Optical density of the solution was measured at $550 \mathrm{~nm}$ wavelength using a microtiter plate reader (Hamilton 7000, Hamilton, Bonaduz, Switzerland). To conduct the neutral red assay, part of the culture medium was replaced by serum starved DMEM containing $11 \mu \mathrm{g} /$ $\mathrm{mL}$ neutral red solution for the neutral red assay. The cultures were thereafter incubated for $60 \mathrm{~min}$ under cell culture conditions, the medium removed and $30 \mu \mathrm{L}$ of Karnovsky fixation fluid was added for $10 \mathrm{~min}$. Thereafter, the cell cultures were washed once with phosphate-buffered saline (PBS), $100 \mu \mathrm{L}$ of isopropanolol- $\mathrm{HCl}$ solution was added and incubated for 15 min before measuring fluorescence at Ex. $530 \mathrm{~nm}$; Em. $645 \mathrm{~nm}$. To conduct culture DNA/Protein assays, the cultures were washed twice with PBS following medium removal. Subsequently, the cultures were incubated in double distilled water, frozen and thawed three times and homogenised by repeated pipetting to produce a culture lysate. Protein content of the lysate was determined using Pierce BCA protein assay kit (Thermo Scientific, Waltham, MA, USA) according to the manufacturer's instructions. DNA measurements, on the other hand, were conducted using the Hoechst assay whereby the lysate was added to Hoechst solution, incubated for $60 \mathrm{~min}$ and evaluated for fluorescence at Ex.: 350 nm; Em.: 460 nm. MTT-formazan, neutral red, bovine serum albumin and calf thymus DNA, respectively, were used as standards for the four assays described in this section.

\section{Cell attachment and spreading}

HBMCs were seeded onto the NS material samples (all feedstock compositions sintered at $1200{ }^{\circ} \mathrm{C}$ ). Cell culture plastic was used as a reference surface. The cell culture experiments were performed in accordance with Bruinink et al. (Bruinink et al., 2005). At day 7 in culture, cells were fixed using $4 \%$ paraformaldehyde containing $0.2 \%$ Trition X-100. Adherent cells were later incubated in Alexa Fluor $^{\circledR} 488$ phalloidin (1:40 from stock in PBS for $60 \mathrm{~min}$, Molecular Probes, Eugene, OR, USA) to label actin microfilaments. Subsequently, the cells were incubated in heat inactivated goat serum to block non- 
specific $\operatorname{IgG}$ binding (10\% in PBS for $60 \mathrm{~min}$ ) then in mouse monoclonal anti-vinculin $\operatorname{IgG}(1: 300 \mathrm{v} / \mathrm{v}$ from stock in PBS overnight, clone hVIN-1, IgG1, Sigma-Aldrich) and finally Alexa Fluor ${ }^{\circledR} 546$ goat anti-mouse $\operatorname{IgG}(1: 100$ $\mathrm{v} / \mathrm{v}$ from stock in PBS for $60 \mathrm{~min}$, Invitrogen) to visualise focal adhesion (FA) plaques.

Cell nuclei were labelled $B O B O^{\mathrm{TM}_{-}} 1$ iodide $(\mathrm{Ex} / \mathrm{Em}$ $=462 / 481 \mathrm{~nm}$, Molecular Probes). Briefly, cellular RNA was removed using $0.3 \mathrm{mg} / \mathrm{mL}$ RNase A (Sigma-Aldrich) in sodium citrate buffer for $60 \mathrm{~min}$ at $37^{\circ} \mathrm{C}$. This was followed by incubation in DMEM and sodium citrate buffer (65\% and $35 \% \mathrm{v} / \mathrm{v}$ respectively) containing $30 \mu \mathrm{g} / \mathrm{mL}$ digitonin (Fluka/Sigma-Aldrich) and 1:300 v/v BOBO ${ }^{\text {TM}_{-}} 1$ iodide).

\section{Focal adhesion (FA) characterisation on microstructured surfaces}

HBMCs were visualised using an LSM 510 upright confocal laser microscope (Carl Zeiss MicroImaging, Oberkochen, Germany). The laser modules used were an Ar laser (458, 477, 488, $514 \mathrm{~nm}) 30 \mathrm{~mW}$ and a HeNe laser $(543 \mathrm{~nm}) 1 \mathrm{~mW}$ through a $63 \mathrm{x}$ water immersion objective lens. 10 random fields were imaged for each sample and for each field. Serial optical sections were acquired at $1 \mu \mathrm{m}$ Z-plane step. The Z stack height ranged between 5 and $30 \mu \mathrm{m}$ depending on the underlying surface topography.

The image stacks of Alexa Fluor ${ }^{\circledR} 546$ labelled FA patches (red channel, Fig. 2a) were projected into single depth coded images, at minimum transparency and 50\% threshold setting, using the LSM Image Browser software (Version 4.2.0.121, Carl Zeiss MicroImaging, Fig. 2b). The depth coding process enabled the precise segmentation of neighbouring-contacting FA plaques. Images were later imported in Image-J software. A manual watershed operation was also applied to further segment FA plaques contacting their neighbours and coloured images were converted into binary/ black and white images using an auto thresholding function (algorithm: threshold = (average background + average objects)/2). This resulted in the further separation of a proportion of the labelled FA plaques present in the image (Fig. 2c). The image was automatically calibrated for scale and all individual FA plaques of $\geq 2 \mu \mathrm{m}^{2}$ were measured for surface area (Fig. 2d). Areas deemed very complex for segmentation and "on-edge" objects were excluded from the analysis. The surface area parameters adopted in this study to characterise FA size described immature FAs as $\leq 2 \mu \mathrm{m}^{2}$; mature FAs as $=2-6 \mu \mathrm{m}^{2}$ and; supermature FAs as $\geq 6 \mu \mathrm{m}^{2}$ (Woodruff et al., 2007).

\section{Cell labelling and cell shape}

In order to evaluate changes in cell morphological conformation of HBMC as a function of the underlying topography, the acquisition of clear images of individual cells was of extreme importance. It was also imperative that cell circumferences were uninterrupted as a result of culture confluence. Labelling of living seeded cells, therefore, took place at day 5 in culture. Following the removal of the culture medium, cells were washed once in PBS and immediately incubated in pre-warmed PBS containing $1 \mathrm{mg} / \mathrm{mL}$ glucose, $1 \mu \mathrm{g} / \mathrm{mL}$ calcein AM (Invitrogen, Basel, Switzerland) and $1 \mu \mathrm{g} / \mathrm{mL}$ DRAQ 5 (Biostatus, Shepshed,
Leics, UK) for $60 \mathrm{~min}$ under cell culture conditions. Subsequently, the labelling solution was removed, the cells washed once with PBS and re-incubated in prewarmed, $1 \mathrm{mg} / \mathrm{mL}$ glucose containing PBS. The cultures were viewed immediately using the LSM 510 confocal laser microscope and image acquisition covered the entire structured and seeded, surface using a 20x objective lens. The laser modules used were an Ar laser (458, 477, 488, $514 \mathrm{~nm}) 30 \mathrm{~mW}$ and a HeNe laser (633 nm) $5 \mathrm{~mW}$.

The use of calcein AM resulted in intense fluorescent staining of the entire cell cytoplasm (Fig. 2e). Following image acquisition, the 2-dimensional conformation of individual cells was digitally characterised using two descriptors of shape that are invariant to both, size and orientation. Firstly, cell elongation was established by calculating the ratio between the major and minor axis of the best fitting ellipse of the cell profile. According to Dunn and co-workers (Dunn and Heath, 1976) the elongation represents the numerical value required to minimise the extension of a particular profile and may, therefore, provide a quantitative parameter in assessing cell morphological responses to the substrate topography. Fluorescence images were processed using Image-J software whereby the best fitting ellipse was obtained representing the uniform distribution of the exact number of pixels enclosed by the cell perimeter (Fig. 2g). The algorithms implemented were verified as directly derived from equations to establish the zero, first and second order moments of inertia. Following the establishment of the ellipses' axis ( $a$ and $b$ ), the elongation (dimensionless) was calculated by:

$$
\mathrm{E}=\log _{2}(a / b)
$$

The second shape descriptor used in this study, compactness, was also computed using Image-J software. The circularity parameter describes the characteristics of a certain geometrical shape relative to that of a circle. It assumes the value of 1 for a perfect circle and decreases, progressively, as the shape become less compact. The dimensionless compactness of cell shapes was computed using the equation:

$$
\mathrm{C}=4 \pi(\text { area }) /(\text { perimeter })^{2}(2)
$$

For both elongation and circularity, only individual cells were analysed excluding cell-cell contacting - and on-edge objects. All parameters were measured in $\mu \mathrm{m}$.

\section{Three-dimensional (3D) iso-surface reconstruction}

To evaluate the spatial patterns of cell-substrate interaction and cell conformation in the third dimension, digital reconstruction of confocal laser microscope images was performed using ImageSurfer software (Version 1.20, University of North Carolina, Chapel Hill, NC, USA) (Feng et al., 2007). Individual confocal (*.1sm) data files representing various cell components (FA patches, actin microfilaments and nuclei) at different channels were used. Additionally, as a result of autofluorescence, surface structures (e.g. hemisphere basis and tips) were visualised by increasing the intensity of the confocal HeNe laser. Iso-surfaces were constructed taking into consideration 
Table 1. Cytotoxicity evaluation. Effects of extracts relative to control incubated medium on 3 T3 fibroblasts regarding total culture DNA and protein content, MTT conversion and neutral red uptake after 5 days of treatment.

\begin{tabular}{|c|c|c|c|c|c|c|c|c|}
\hline \multirow[t]{2}{*}{ Sample } & \multicolumn{2}{|c|}{ DNA } & \multicolumn{2}{|c|}{ MTT } & \multicolumn{2}{|c|}{ Protein } & \multicolumn{2}{|c|}{ Neutral red } \\
\hline & control & extract & control & extract & control & extract & control & extract \\
\hline \multicolumn{9}{|c|}{ Feedstock I } \\
\hline NS & $100.0 \pm 9.5$ & $74.6 \pm 14.5$ & $100.0 \pm 5.5$ & $108.3 \pm 3.9$ & $100.0 \pm 4.4$ & $103.5 \pm 5.2$ & $100.0 \pm 4.5$ & $107.8 \pm 7.5$ \\
\hline $30 \_20$ & $100.0 \pm 25.4$ & $67.0 \pm 7.1$ & $100.0 \pm 4.0$ & $104.8 \pm 8.7$ & $100.0 \pm 3.5$ & $112.9 \pm 3.3$ & $100.0 \pm 4.0$ & $112.9 \pm 3.3$ \\
\hline $50 \_20$ & $100.0 \pm 16.8$ & $89.7 \pm 16.0$ & $100.0 \pm 6.9$ & $79.9 \pm 10.6$ & $100.0 \pm 3.0$ & $125.1 \pm 4.4$ & $100.0 \pm 3.6$ & $113.3 \pm 5.2$ \\
\hline \multicolumn{9}{|c|}{ Feedstock IV } \\
\hline NS & $100.0 \pm 14.3$ & $72.9 \pm 10.1$ & $100.0 \pm 19.1$ & $155.9 \pm 8.0$ & $100.0 \pm 6.1$ & $85.0 \pm 5.9$ & $100.0 \pm 6.8$ & $89.4 \pm 4.5$ \\
\hline $30 \_20$ & $100.0 \pm 13.8$ & $109.5 \pm 7.5$ & $100.0 \pm 9.6$ & $137.4 \pm 14.7$ & $100.0 \pm 6.0$ & $135.7 \pm 12.3$ & $100.0 \pm 5.7$ & $117.5 \pm 5.7$ \\
\hline $50 \_20$ & $100.0 \pm 3.7$ & $89.9 \pm 4.5$ & $100.0 \pm 19.1$ & $64.3 \pm 10.4$ & $100.0 \pm 11.8$ & $114.0 \pm 3.7$ & $100.0 \pm 5.8$ & $116.2 \pm 6.3$ \\
\hline
\end{tabular}

the voxel height ( $\mathrm{Z}$ spacing) and width (XY spacing) of the imaged sample and later exported into Wavefront object $(*$.obj) data files. These, in turn, were processed using Caligari Truespace software (Version 3.2, Caligari Corp., Redmond, WA, USA) to generate demonstrative 2 dimensional raster images at various perspective points (Lim et al., 2005). Where applicable, surface patterns (i.e., hemispheres) were reproduced using non uniform rational basis spline (NURBS) 3D modelling.

\section{Statistical analysis}

Cell-surface interaction experiments were carried out in triplicate, and repeated three times using three different donor patient cells. To illustrate differences in biological responses as a function of topography, the data for each individual experiment were pooled from the three samples and a continuous descriptive analysis took place using S-PLUS $^{\circledR}$ software (Version 6.2, TIBCO Software Inc., Palo Alto, CA, USA) to establish the sample size $(N)$, mean $(M)$ and standard deviation $(S D)$ for each study. To statistically verify the presence of an overall crossstudy trend, meta analysis was carried out using the MIX software package (Version 1.61, Kitasato Clinical Research Centre, Kanagawa, Japan) (Bax et al., 2006; Sutton and Higgins, 2008). Meta analysis was performed for continuous outcome data using the Hedges's g association measure. The standardised mean difference between 2 different variants (e.g., 50_20 vs. NS) was calculated, using the random effects model, as follows,

$$
\mathrm{HG}[\text { corrected }]=(\mathrm{MD} / \mathrm{SD}[\text { pooled }]) *(1-3 /(4 * \mathrm{~N}-9))
$$

where $H G$ is Hedges's g standardised mean difference, $M D$ is the mean difference and $N$ is the sample size. And,

$$
\mathrm{MD}=\mathrm{m}[e]-\mathrm{m}[c]
$$

where $c$ and $e$ are the experimental variants and,

$\mathrm{SD}[$ pooled $]=\operatorname{SQRT}\left(\left((\mathrm{n}[e]-1)^{*} \operatorname{SD}[\mathrm{e}]^{\wedge} 2+(\mathrm{n}[c]-1)^{*} \operatorname{SD}[c]^{\wedge} 2\right) /(\mathrm{N}-2)\right)(5)$

The standard error for the $H G$ value was calculated by,

$$
\mathrm{SE}[\mathrm{HG}, \mathrm{i}]=\mathrm{SQRT}\left(\mathrm{N} / \mathrm{n}[\mathrm{e}] * \mathrm{n}[\mathrm{c}]+\mathrm{HG}^{\wedge} 2 /(2 *(\mathrm{~N}-3.94))\right)
$$

The random effects model was chosen to accommodate for source variability (i.e. the patients), the heterogeneity of the HMBC population and the potential variation in experimental conditions.

S-PLUS ${ }^{\circledR}$ software was also used to conduct one-way analysis of variance (ANOVA) to evaluate differences in surface roughness values. Multiple comparisons were conducted using Bonferroni post-hoc correction at $95 \%$ confidence interval. In all instances in this study, an $\alpha$ level- $P$ value of $\leq 0.05$ was considered indicative of significance.

ISO 109335 test (Cytotoxicity) results were statistically evaluated using Students $t$-test.

\section{Results}

\section{Sintered surface characterisation}

EDS evaluation of the sintered samples showed surface composition of $18.99 \pm 0.38 \%$ chromium, $12.27 \pm 0.37 \%$ nickel and $2.78 \pm 0.08 \%$ molybdenum (related to austenitic stainless steel AISI 316L alloy). The values obtained also correspond to medical grade (ISO 5832-1) standard stainless steel defined by a content of nickel 10-14\%, chromium $16-18 \%$ and molybdenum $2-3 \%$. In this respect, the sintered samples were characterised by relative density value of of $97.4 \% \pm 1.2 \%$. Surface roughness values ranged between $(\mathrm{Sa})$ of $410 \pm 50 \mathrm{~nm}(0 \%$ nano powder addition) to $530 \pm 40 \mathrm{~nm}$ (33.3\% nano powder addition). Based on SEM evaluation, the structured surfaces were composed of a reproducible array of hemispheres with the following dimensions (feedstock I) for $30.0 \pm 0.2 \mu \mathrm{m}$ hemisphere diameter, $12.1 \pm 0.1 \mu \mathrm{m}$ hemisphere height and $17.2 \pm 0.3 \mu \mathrm{m}$ interspacing distance termed 30_20 surface and $46.4 \pm 0.6 \mu \mathrm{m}$ hemisphere diameter, 26.4 $\pm 0.6 \mu \mathrm{m}$ hemisphere height and $18.5 \pm 0.2 \mu \mathrm{m}$ interspacing distance termed 50_20 surface (Fig. 1a,b and comparison NS surfaces in Fig. 1c).

\section{Effects of released components by the sintered samples}

According to the ISO 10993-5 norm, material extracts are defined as toxic if the corresponding cell viability rate, as indicated by DNA and protein content, were below $70 \%$ of those associated with the control cells (i.e., cells incubated under typical cell culture conditions). With the exception of culture DNA values associated with FS-I 30_20 extracts and the culture protein values associated with NS IV 50_20 extracts (both of which not significantly 

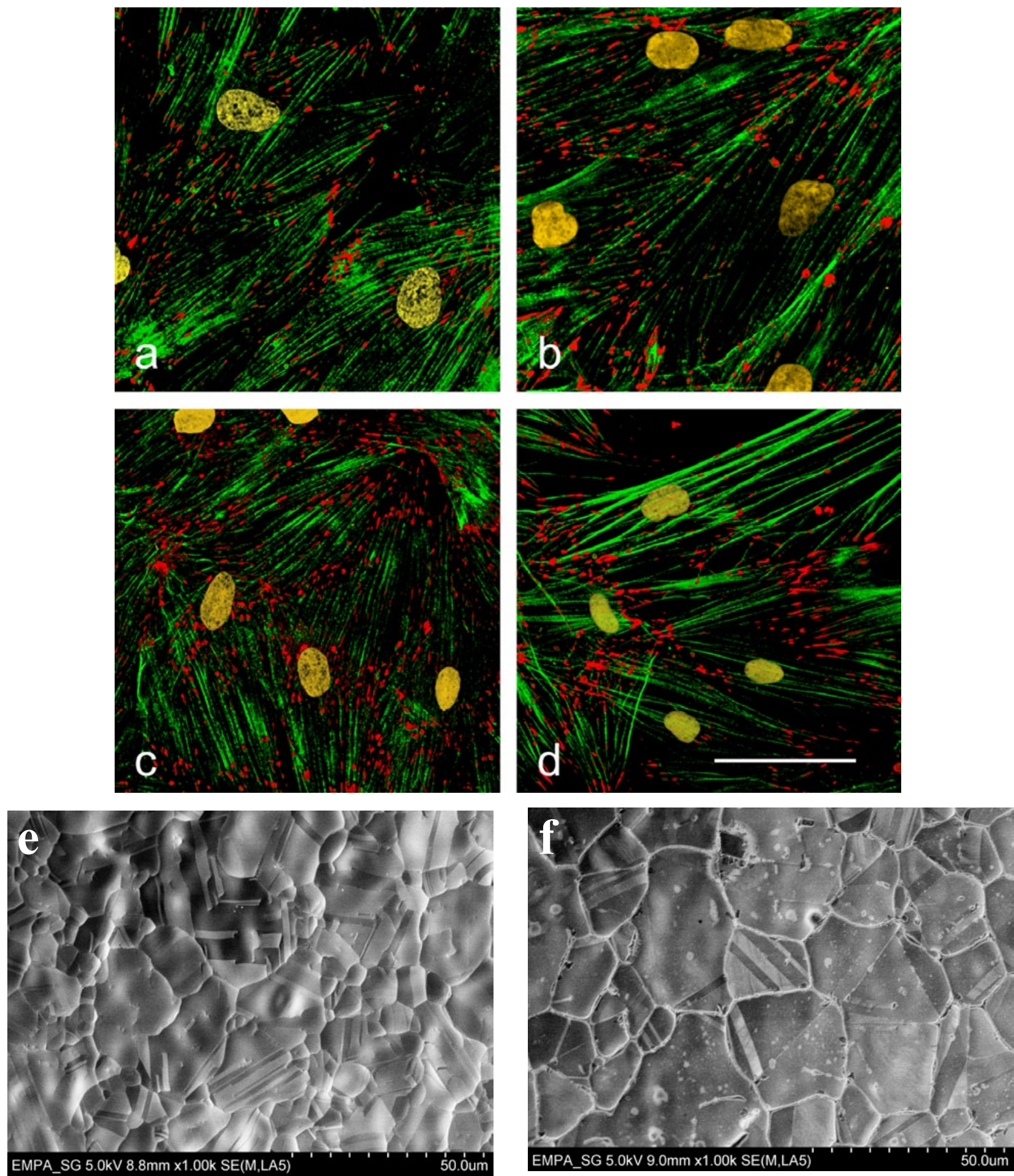

Fig. 3. Confocal laser microscope images of HBMC cells cultured on NS surfaces sintered from Feedstock II, III and IV at $1200{ }^{\circ} \mathrm{C}$ (a, b, and $\mathbf{c}$ respectively). Fluorescence labelling was used to visualise the actin cytoskeleton (green), the FA vinculin protein (red) and the cells nuclei (yellow). Cells seeded on control cell culture dish surfaces are shown in Fig. (d). The corresponding scanning electron micrographs are presented in (e), (f), and (g) for feedstock II, III and IV, respectively. (Hitachi 54800 scanning electron microscope; Working distance: $9 \mathrm{~mm}$, no coating, EHT: $5 \mathrm{kV}$ ).

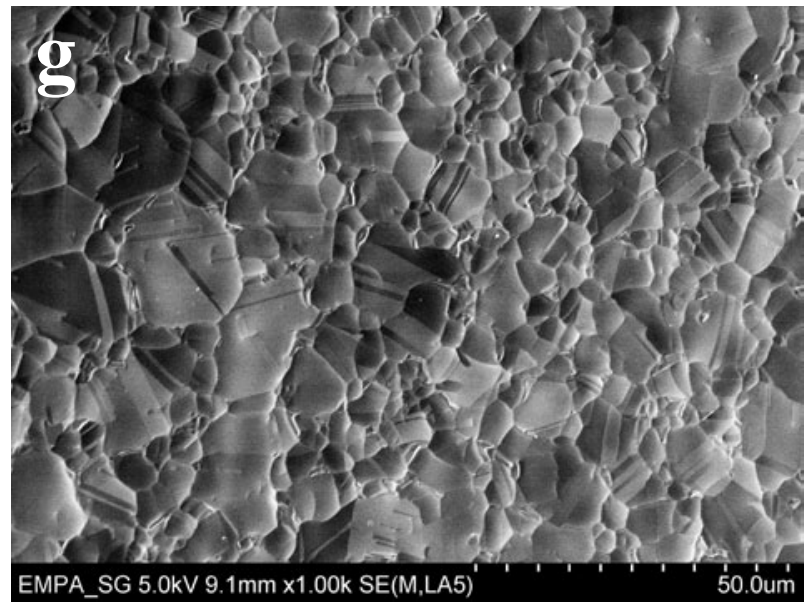



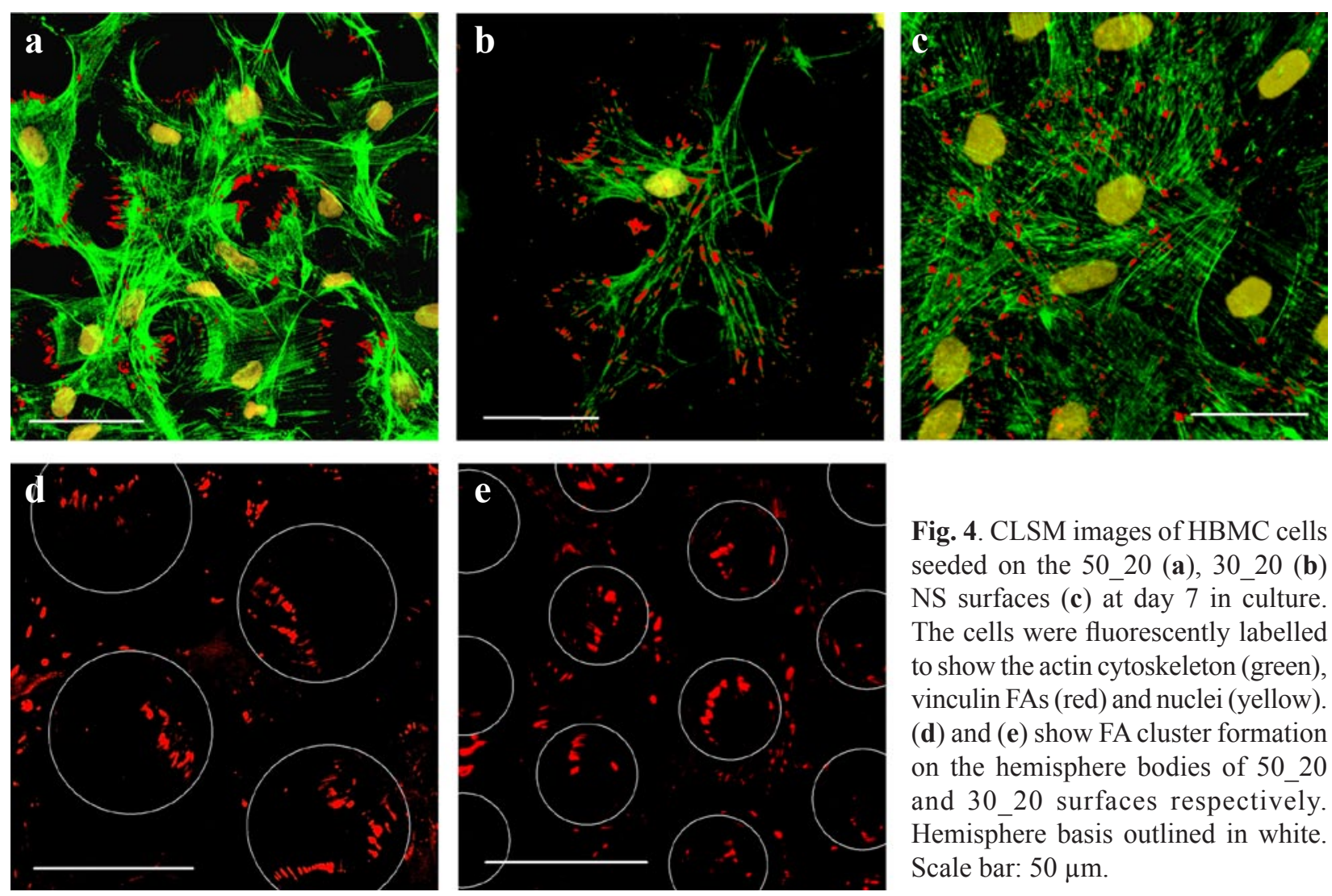

Fig. 4. CLSM images of HBMC cells seeded on the 50_20 (a), 30_20 (b) NS surfaces (c) at day 7 in culture. The cells were fluorescently labelled to show the actin cytoskeleton (green), vinculin FAs (red) and nuclei (yellow). (d) and (e) show FA cluster formation on the hemisphere bodies of 50_20 and 30_20 surfaces respectively. Hemisphere basis outlined in white. Scale bar: $50 \mu \mathrm{m}$.
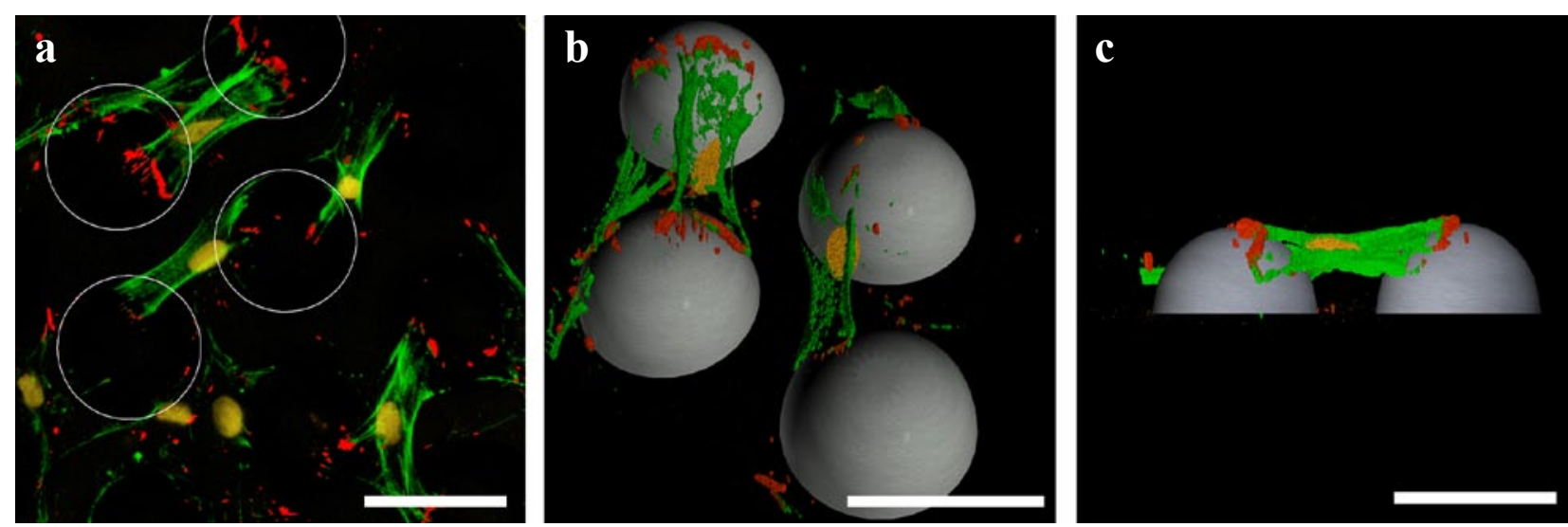

Fig. 5. 3D isosurface construction of HBMC cells seeded on the 50_20 surface at day 7 in culture (a). The cells were fluorescently labelled to show the actin cytoskeleton (green), vinculin FAs (red) and nuclei (yellow). (b) and (c) show XYZ and XZ perspectives respectively. Scale bar: $50 \mu \mathrm{m}$.

below $70 \%$ ); all the obtained values in this study were above $70 \%$ compared to control values (obtained for the control cultures). Overall, and considering all the assays conducted in this study, the surfaces may be described as cytocompatible (not-toxic) as seen in Table 1. Cell attachment and spreading of HBMCs were also maintained on the seeded NS sample surfaces obtained from feedstock I, II, III and IV (Fig. 3 - Images for feedstock I not shown). On the NS samples, the seeded HMBCs exhibited wide spread morphology with intensive actin microfilament formation. Cell density, spreading and morphology were similar on the NS samples made of different feedstocks and comparable to that on control cell culture dish surfaces.
Cell attachment to the NS surfaces (all feedstock variants) was also characterised by the intensive formation of dense patches of vinculin FAs at the focal adhesion sites clearly confirming the cytocompatible nature of the various surfaces.

\section{Modulation of cell attachment by surface} microstructuring and morphological arrangement By day 7 in culture, microstructured surfaces were covered by dense populations of HBMCs exhibiting well spread morphology (Fig. 4a-c). Cell attachment to the surfaces was characterised by a defined actin cytoskeleton and the formation of dense FA patches. Interestingly, and on 
a

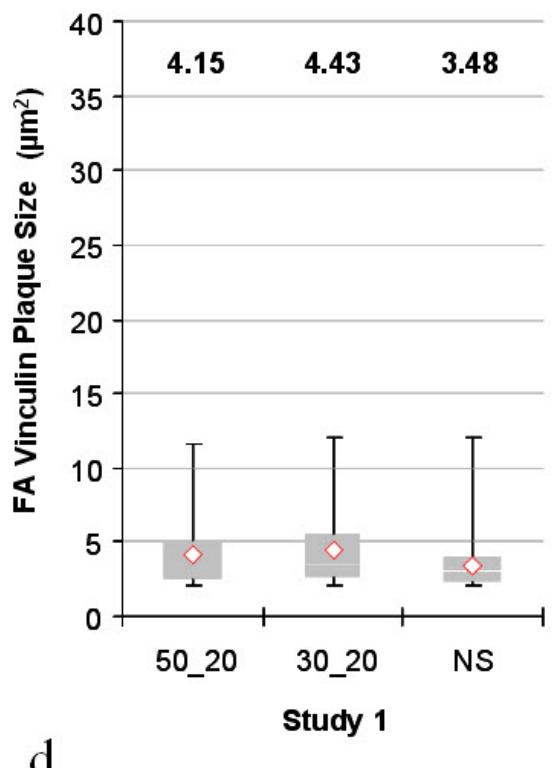

d

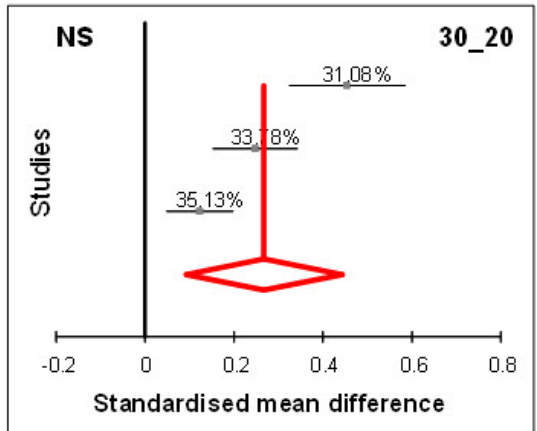

b

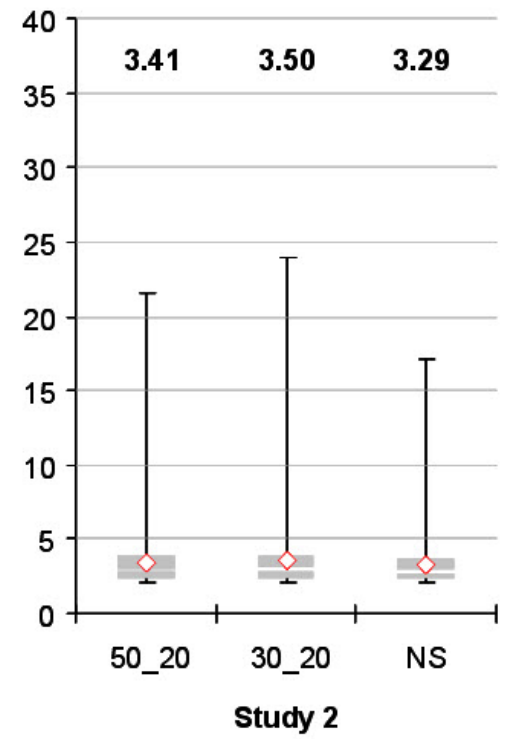

e

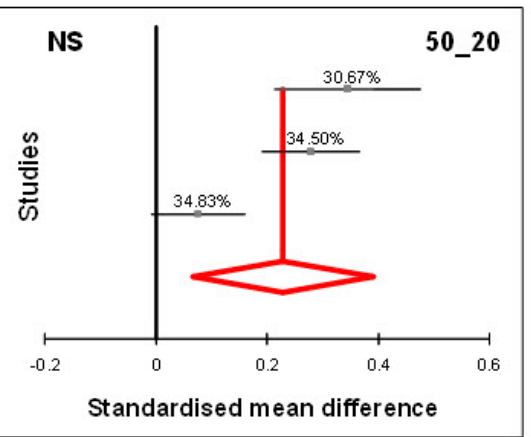

$\mathrm{c}$

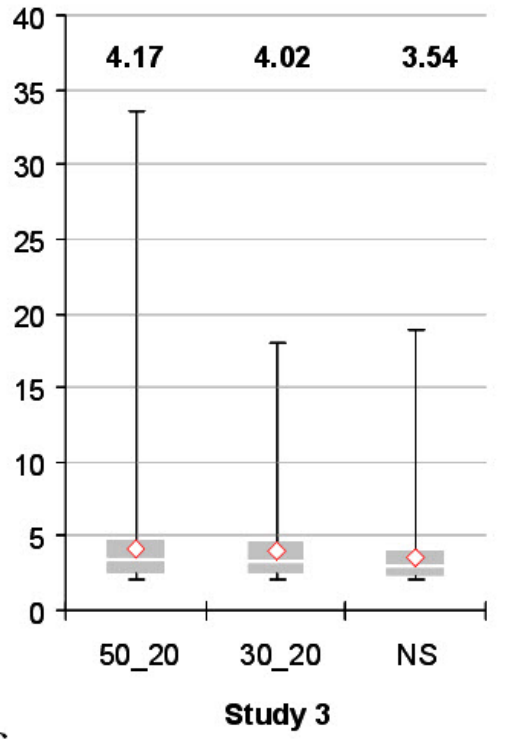

$\mathrm{f}$

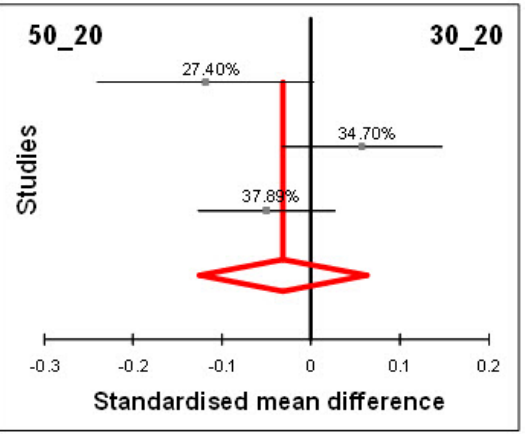

Fig. 6. Effects of different surface structuring on focal adhesion size. (a) Box plots showing the distribution and mean values of FAs area size as a function of surface topography for the 3 independent studies using 3 different donor cells. Standard forest plots of Meta analysis of effect (diamond) of FAs size comparison as a function of surface topography using Hedges's g association measure. (b), (c) and (d) show the effects of 30_20 vs. NS, 50_20 $v s$. NS and 50_20 vs. 30_20 respectively. The data were pooled from 3 independent studies using HBMC cells from different patients. Each study is represented by a gray square marked for the confidence interval (horizontal line) and study weight (\%). The vertical line (at X value 0 ) represent the no-effect region.

both 50_20 and 30_20 surfaces, FAs appeared to cluster in parallel and in close proximity when in contact with the hemisphere structures (Fig. 4d,e). Noticeably, the clustered FAs were arranged in a way that their longest axis was in parallel with the associated actin stress fibres. This arrangement was not present on the NS surfaces were FA spatial distribution took a randomised pattern. Further examination of the 3D arrangement of the cell cytoskeleton (Fig. 5) revealed that the cell-substrate contact, i.e., where FA clustering was present, was almost exclusively limited to the hemisphere area. In fact, and on several occasions, the seeded cells were exclusively attached to the hemispheres with no contact with the plain, inter-hemisphere surface component.

\section{Modulation of FA size}

On all surfaces, FA patches up to $\approx 37 \mu \mathrm{m}^{2}$ were present (data not shown). Higher mean size values of mature and super mature FAs were, however, associated with 50_20 and $30 \_20$ surfaces when compared to the NS controls (Fig. $6 a)$. Meta analysis of the pooled experiments revealed a significant increase in FA plaque size on both, 50_20 and 30_20 surfaces compared to the NS controls (Fig. 6b,c). No significant difference in FA plaque size was present between the 50_20 and 30_20 surfaces (Fig. 6d).

\section{Modulation of cell shape}

As expected, 3D iso-surfacereconstruction of Calcein AM/ DRAQ 5 confirmed the nature of cell-hemisphere topography interaction (Fig. 7). In several instances, HBMC cells were appeared exclusively attached to the hemisphere bodies with limited or no contact with the flat surface between the hemisphere bases. As a result, the cells exhibited unique 3D morphology characterised by a clear increase in the cytoskeleton vertical height.

Besides quantifying different morphological cell responses to different surface topographies, the definition of shape descriptors may further aid in explaining the 

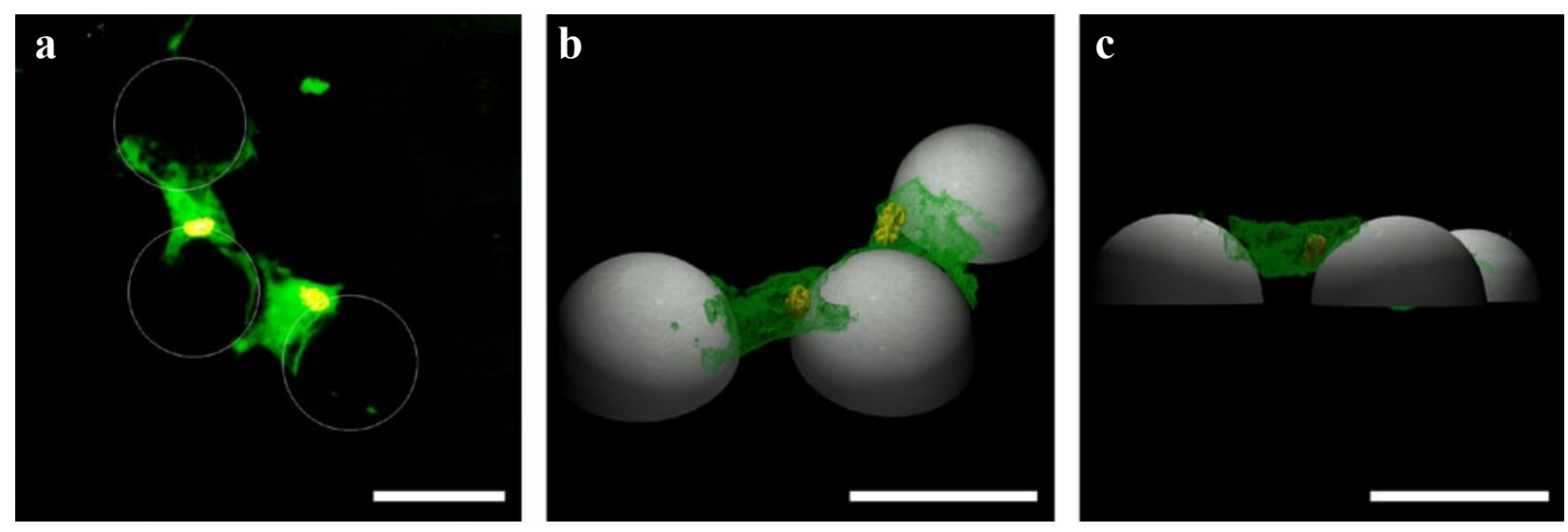

Fig. 7. 3D isosurface construction of HBMC cells seeded on the 50_20 surface at day 5 in culture (a). Live cells were fluorescently labelled to show the cytoplasm (green, Calcein AM) and the nuclei (yellow, DRAQ 5). (b) and (c) show XYZ and XZ perspectives respectively. Scale bar: $50 \mu \mathrm{m}$.

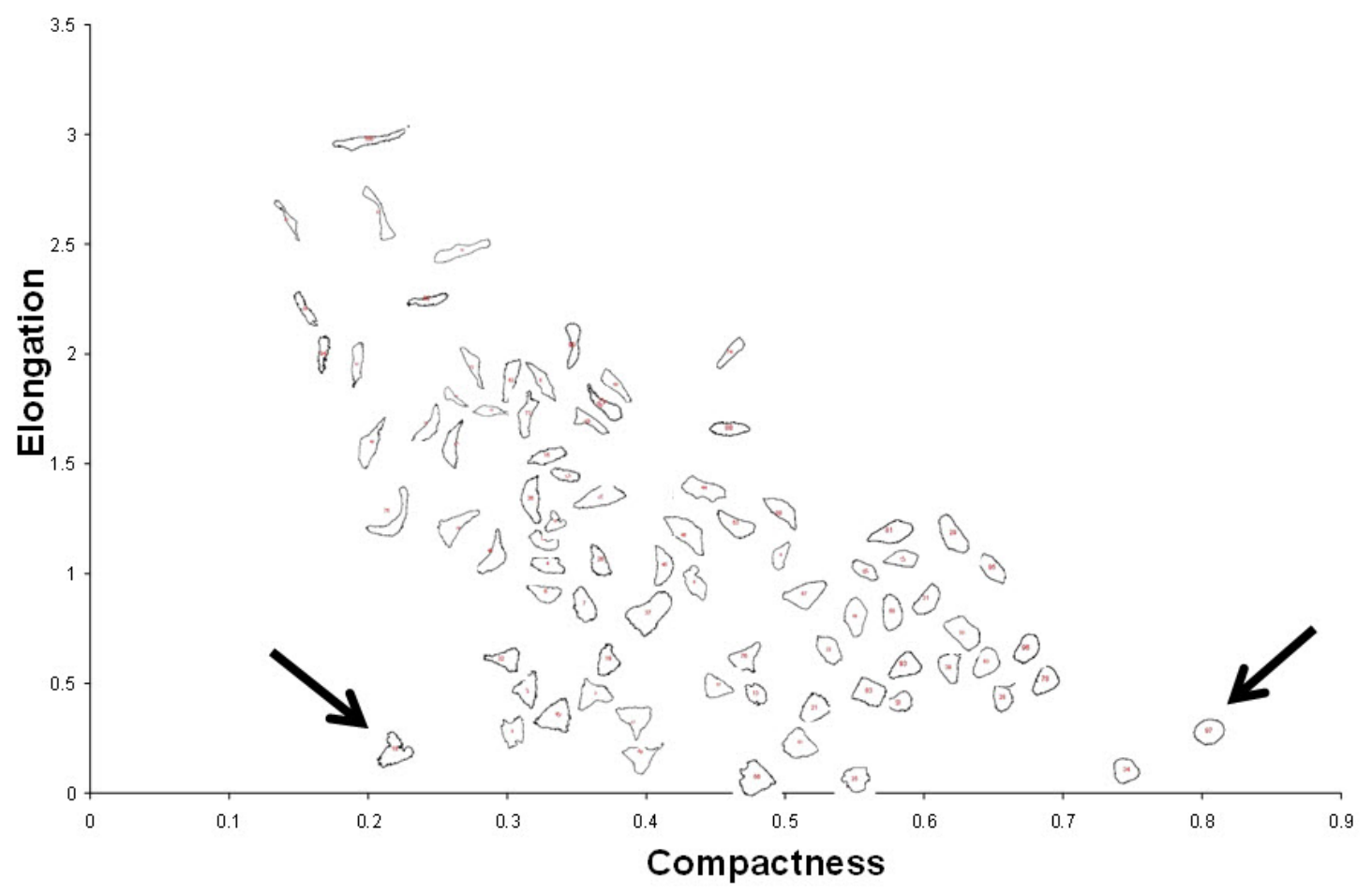

Fig. 8. An XY plot of cell silhouettes according to compactness and elongation values. The plot shows 100 cells seeded on the $50 \_20$ surfaces at day 5 in culture. The cells indicated using black arrow heads share similar elongation values and differ markedly in their circularity and border complexity.

parameters leading to such differences. In this respect, and in several studies, the compactness descriptor has been used to describe the robustness, circularity and complexity of shape (Middleton et al., 1988; Weber, 1999; Shouche et al., 2001; Horváth et al., 2006). To better define the geometrical variants expressed by different compactness values, a representative XY scatter plot combining the compactness and elongation values for a 100 randomly selected individuals was generated as seen in Fig. 8. A clear and consistent categorisation of cells was apparent as a result of both, compactness and elongation of shape. A strong reciprocal relationship between cell elongation and compactness can be observed whereby; a relative tendency for increased elongation appears to be associated with decreased compactness and vice versa. More importantly, it can be also seen that cells sharing similar elongation values differ in their border regularity as a function of compactness. Compactness, therefore, appeared to be primarily an expression of the complexity of the cell border.

In this regard, a significant increase in cell shape compactness was associated with the 50_20 and 30_20 surfaces compared to the NS surfaces (Fig. 9a,b). Despite a tendency for decreased cell elongation on the structured surfaces compared to the NS controls, statistical metaanalysis showed no significant difference in elongation as a function of surface topography (results not shown). 
a

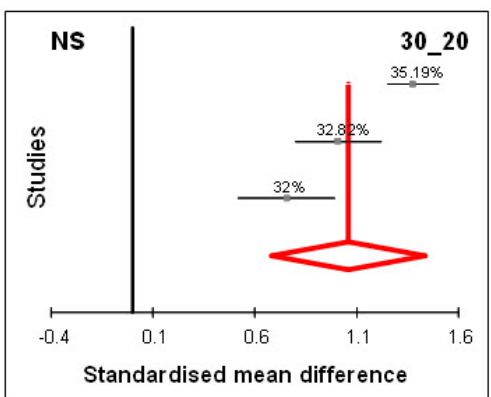

b

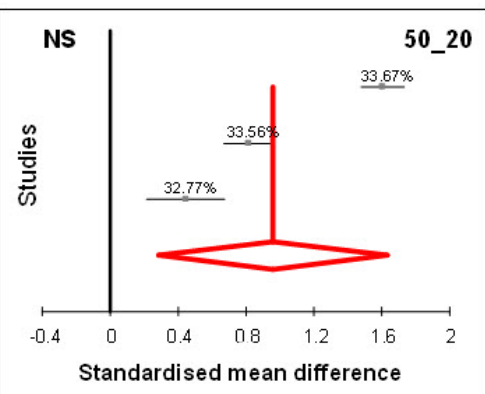

$\mathrm{c}$

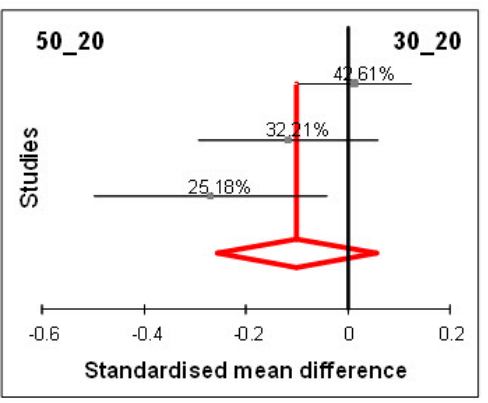

Fig. 9. Standard forest plots of Meta analysis of effect (diamond) of cell shape compactness values as a function of surface topography using Hedges's g association measure. (a), (b) and (c) showing the effects of 30_20 vs. NS, $50 \_20 v s$. NS and 50_20 vs.30_20 respectively. The data were pooled from 3 independent studies using HBMC cells from different patients. Each study is represented by a gray square marked for the confidence interval (horizontal line) and study weight (\%). The vertical line (at X value 0 ) represent the no-effect region.

\section{Discussion}

In this report, we investigated the biological effects of metal surfaces produced by an optimised $\mu$-MIM process with $\mu \mathrm{m}$-scale pattering and defined sub- $\mu \mathrm{m}$-scale roughness. This process was used as a platform to produce hemisphere microarray surface topography of two size variations in terms of hemisphere diameter and the nearest equidistance between adjacent hemisphere bases. Cell responses to the presence and size variations of the produced surface topography arrays were evaluated following cytotoxicity and cytocompatibility evaluation.

$\mu \mathrm{m}$ - and sub- $\mu \mathrm{m}$-scale variations (roughness) in substrate surface topography have been identified as a major bioactive parameter promoting both, osteogenic differentiation and mineralised bone extracellular matrix (ECM) formation (Aparicio et al., 2002; Boyan et al., 2003; Huang et al., 2004). It is becoming evident however, that unlike conventional "randomised roughening", the presence of defined and ordered topographical fictionalisation of substrate surfaces may deliver precise and controllable biomechanical cues to collectively influence cell population dynamics (Meyle et al., 1993; Dan, 2000; Liao et al., 2003; Hamilton et al., 2005). Several ordered $\mu \mathrm{m}$ and sub- $\mu \mathrm{m}$ surface structural patterns have since been evaluated for their bioactive characteristics (Ball et al., 2008; Biggs et al., 2008; Engel et al., 2009).

Recently, a pilot study by our group investigated the influence of ordered topography of polystyrene surfaces on rat bone marrow cell morphology, ALP and DNA expression (Bruinink et al., 2005). Marked effects on cell behaviours were associated with these novel surface features, in the form of protruding $\mu \mathrm{m}$-scale hemisphere arrays, as significant changes in cell cytoskeleton organisation were induced. This was particularly associated with hemisphere diameter of $30 \mu \mathrm{m}$, and inter-hemisphere distance of $20 \mu \mathrm{m}$, as cell lamellipodia preferentially attached to the hemisphere bodies. Additionally, an upregulation in ALP protein expression levels was associated with hemispheres of $50 \mu \mathrm{m}$ in diameter. In this study, and as a first step towards the production of stable full scale bioactive titanium implants without biofunctionalisation with unstable biological molecules, we aimed at utilising the $\mu$-MIM process replicate the potentially bioactive hemisphere arrays on metal surfaces. To date, however, a comprehensive evaluation of hemisphere array biological effects remains lacking. Such patterns present multiple bioactive topography features such as, (i) - contact guidance as a function of the defined edges of hemisphere bases (Clark et al., 1987; Clark et al., 1990); (ii) - gap guidance between the hemisphere bodies and (Hamilton et al., 2005; Hamilton et al., 2006); (iii) - curvature surface features resulting from the hemisphere shape (Löfberg and Ebendal, 1980). An additional bioactive outcome may also result from using the $\mu$-MIM process in the form of sub- $\mu \mathrm{m}$-scale surface roughness.

The stainless steel surfaces produced by the $\mu$-MIM sintering process exhibited well defined hemisphere arrays with an additional, sub- $\mu \mathrm{m}$-scale, topography variation as a result of metal grain boundary formation. To eliminate experimental variations resulting from spatial distribution, the hemispheres were arranged at an equidistance whereby any bioactive characteristics were relatively confined to the presence, and size variations, of the hemispheres. Similarly, the plain controlled surfaces were produced using the same methodology bearing the same sub- $\mu \mathrm{m}$ surface patterns.

We have assessed the in vitro biological effect of the hemisphere arrays, using two hemisphere size variations, at a "microscopic level" by evaluating specific cytoskeleton features (FA size variations, actin conformation and 3D morphology). In this respect, immunolabelling of vinculin FA on the 30_20 and 50_20 surfaces revealed the presence of FAs clustering within the hemispheres boundaries. These clusters, following 3D construction of CLSM images, were clearly connected to the actin stress fibres where cells were almost exclusively attached to the hemisphere bodies. The presence of this unique, "quasisuspended", 3D conformation confirms that the rigidity of the cell cytoskeleton is sufficient to accommodate multiple topographical substrate features (Ohara and Buck, 1979). Following FAs size quantification, a significant increase in mature and supermature FA formation took place on the 30_20 and 50_20 surfaces. This may be attributed to an increase in the intracellular forces applied to the 
surface to maintain the cytoskeleton $3 \mathrm{D}$ conformation as the overall cell-substrate contact was nearly reduced to the hemisphere bodies. This is in line with a report by Balaban et al. demonstrating a strong correlation between the force and the area size of FAs (Balaban et al., 2001). It has also been reported that the transformation from focal complexes into mature FAs results from Rho regulated, contractile, intracellular forces (Allen et al., 1997; Dugina et al., 2001). This transformation appears to be necessary to maintain isometric tension and may regulate key downstream signalling events such as tyrosine phosphorylation (Wozniak et al., 2004; Hamilton and Brunette, 2007). This has been strongly linked to promoting osteogenic commitment of human mesenchymal stem cells and may prove critical since the initial phase of peri-implant osteogenesis is performed mainly by newly recruited, and subsequently differentiated, immature osteoprogenitor cells (Albrektsson et al., 1981; Davies, 2003; McBeath et al., 2004). The 30_20 and 50_20 hemisphere microarray patterns may, therefore, present bioactive cues promoting the osteogenesis of recruited cells.

It was extremely important, nonetheless, to initially quantify changes in the cytoskeleton morphology across the entire microstructured surface and the entire seeded cell population. Accordingly, we opted for analysing the fluorescence silhouettes of individual cells using two descriptors of shape - elongation and compactness. Here, our data showed no changes in cell elongation induced by the hemisphere microarray topography compared to the planar controls. On the contrary, a significant increase in cell shape compactness was associated with the presence of the hemisphere and for both hemisphere size variations. As highlighted in the results section of this report, compactness values were primarily linked to cell border complexity. We attribute this event to the overall decrease in cell-substrate contact as cell attachment became strongly limited to the hemisphere bodies. This is subsequently reflected in limiting the proportion of cell border capable of forming complex protrusions. We may thus conclude that on the surfaces exhibiting ordered hemisphere structures the seeded marrow stromal cell population was collectively induced to assume a unique 3D conformation induced by a selective cell-substrate attachment and an increased vertical height of the cytoskeleton. It is generally agreed, that cell shape and orientation on structured substrates are modulated by contact guidance. Here, initially, cell topography feature contact may have been modulated by the continuous edges of the hemisphere bases. The presence of this well-defined feature may result in guiding the conformation of actin microfilaments, microtubules and focal contacts (Andersson et al., 2003). Additionally, cell "positioning" between the hemispheres bodies may result, in line with Hamilton and co-workers from gap guidance of cell motility on discontinuous edge surfaces (Hamilton et al., 2006). In this respect, the presence of a specific distance between the hemisphere bases (e.g., nearly $20 \mu \mathrm{m}$ in this study) may play a critical role in single cells sensing multiple topographical features. The subsequent mechanisms guiding cell conformation in the vertical dimension remain unclear however; we suggest that the curved nature of the hemispheres surfaces may have provided certain guidance cues. It has been shown that the presence of curved microtopographies markedly induced cell motility in specific directions. This induction appeared to transcend the influence of other surface features such as grooves and edges (Santos et al., 2005; Zhao et al., 2006). In this report, and in relation to cell guidance by the hemisphere structures, we propose using the description "vertical gap guidance" as the cytoskeleton morphological changes took place in vertical dimension. Finally, an "entrapment" of cell volume may occur as a result of the polarisation of the cytoskeleton between the adjacent hemispheres and the restricted ability of the cell to create successful protrusions (Dunn, 2000). This "focused" cell attachment pattern to the hemisphere bodies may impose restrictions on cell motility thus, potentially, regulating cell proliferation and differentiation (Lee et al., 2004). At this stage, however, it would be inappropriate to relate this hypothesis to the microtopography arrays evaluated in this study. Live cell motility experiments are currently underway to examine the spatial, and temporal, nature of cell migration trajectory patterns on the hemisphere microarray surfaces.

We have demonstrated that the 30_20 and 50_20 hemisphere arrays, using sintered 316L stainless steel, significantly regulated key cellular components such as FA regulation and cytoskeleton organisation. This impact may be related to combined contact, gap and vertical gap guidance resulting from the multi-feature nature of the surface arrays. This appeared to be strongly linked to the shape of the hemispheres and the specific distance between the hemisphere bodies. It must be also noted that $\mu$-MIM process produced hierarchical surface features by combining $\mu \mathrm{m}$ and sub- $\mu \mathrm{m}$-scale patterns. Optimising the relationship between these two orders of scale, by varying the feedstock nanopowder content, may further increase the osteogenic effects of these surfaces (Zhao et $a l ., 2007)$. Here, the role of grain boundaries in modulating cell reaction remains to be investigated.

Overall, the results shown in this study further confirmed that the effect on cells by these surfaces was linked primarily to their topography. It is well acknowledged that surface chemistry also plays a role in how far the surface affect cell functionality together with other physical characteristics such as material rigidity. As we ultimately aim at producing $\mu$-MIM structured titanium implants, these factors must be also considered so that the cytocompatibility, and effects on cell functionality, related to these surfaces is further investigated. Here, and besides an expected increase in bulk material mechanical properties, the production of titanium based implants is projected to achieve optimal osteointegration in-vivo (titanium as the gold standard material for orthopaedic implants).

At a medical device production level, the next main step for this project would be the design of a moulding process whereby $\mu$-MIM sintered/ structured orthopaedic implants may be produced. This must be followed, at a later stage, by optimising the technical platform parameters so that this process may be scaled up at an industrial scale. 
Ultimately, titanium $\mu$-MIM structured units may target clinical applications such as bone fixation device parts, bone graft substitutes and dental implants.

\section{Conclusion}

The presence of the protruding, $\mu \mathrm{m}$-scale, hemispheres significantly altered human bone marrow stromal cell behaviour resulting in an increase in large FA suggesting that these surfaces are able to induce mature and supermature FAs formation and a unique 3D cytoskeleton conformation. Increased FA may play a role in the promoting osteogenic commitment in precursor cells by the hemisphere microtopography. Surface topography patterning using $\mu$-MIM process, together with $\mu \mathrm{m}$-scale hemisphere structures, will be taken forward towards the one-step production of bioactive orthopaedic titanium implants.

\section{Acknowledgements}

The authors acknowledge the generous support of the Volkswagen Foundation (contract nr. 182-296) in Germany.

\section{References}

Albrektsson T, Brånemark PI, Hansson HA, Lindström J (1981) Osseointegrated titanium implants. Requirements for ensuring a long-lasting, direct bone-to-implant anchorage in man. Acta Orthop Scand 52: 155-170.

Allen W, Jones G, Pollard J, Ridley A (1997) Rho, Rac and $\mathrm{Cdc} 42$ regulate actin organization and cell adhesion in macrophages. J Cell Sci 110: 707-720.

Andersson A, Olsson P, Lidberg U, Sutherland D (2003) The effects of continuous and discontinuous groove edges on cell shape and alignment. Exp Cell Res 288: 177-188.

Aparicio C, Gil FJ, Planell JA, Engel E (2002) Humanosteoblast proliferation and differentiation on grit-blasted and bioactive titanium for dental applications. J Mat Sci: Mat in Med 13: 1105-1111.

Balaban NO, Schwarz US, Riveline D, Goichberg P, Tzur G, Sabanay I, Mahalu D, Safran S, Bershadsky A, Addadi L, Geiger B (2001) Force and focal adhesion assembly: a close relationship studied using elastic micropatterned substrates. Nat Cell Biol 3: 466-472.

Ball M, Grant DM, Lo W, Scotchford CA (2008) The effect of different surface morphology and roughness on osteoblast-like cells. J Biomed Mat Res A 86A: 637-647.

Bax L, Yu L, Ikeda N, Tsuruta H, Moons K (2006) Development and validation of MIX: comprehensive free software for meta-analysis of causal research data. BMC Med Res Methodol 6: 50.

Biggs MJP, Richards RG, Gadegaard N, McMurray RJ, Affrossman S, Wilkinson CD, Oreffo RO, Dalby MJ (2008) Interactions with nanoscale topography: Adhesion quantification and signal transduction in cells of osteogenic and multipotent lineage. J Biomed Mat Res A 79A: 431439.

Bordji D, Jouzeau J, Mainard D, Payan E, Netter P, Rie KT, Stucky T, Hage-Ali M (1996) Cytocompatibility of Ti$6 \mathrm{Al}-4 \mathrm{~V}$ and Ti-5 Al-2.5Fe alloys according to three surface treatments, using human fibroblasts and osteoblasts. Biomaterials 17: 929-940.

Born AK, Rottmar M, Lischer S, Pleskova M, Bruinink A, Maniura-Weber K (2009) Correlating cell architecture with osteogenesis:firsts steps towards live single cell monitoring. Eur Cell Mater 18: 49-62.

Boyan BD, Lossdorfer S, Wang L, Zhao G, Lohmann CH, Cochran DL, Schwartz Z (2003) Osteoblasts generate an osteogenic microenvironment when grown on surfaces with rough microtopographies. Eur Cell Mater 6: 22-27.

Bruinink A (1992) Serum-free monolayer cultures of embryonic chick brain and retina: immunoassays of developmental markers, mathematical data analysis and establishment of optimal culture conditions. In: The Brain in Bits and Pieces (Zbinden G, ed), MTC Verlag, Zollikon, pp 23-30.

Bruinink A, Wintermantel E (2001) Grooves affect primary bone marrow but not osteoblastic MC3T3-E1 cell cultures. Biomaterials 22: 2465-2473.

Bruinink A, Kaiser J-P, Meyer DC (2005) Effect of biomaterial surface morphologies on bone marrow cell performance. Adv Eng Mat 7: 411-418.

Clark P, Connolly P, Curtis AS, Dow JA, Wilkinson CD (1987) Topographical control of cell behaviour: I. Simple step cues. Development, 99: 439-448.

Clark P, Connolly P, Curtis AS, Dow JA, Wilkinson CD (1990) Topographical control of cell behaviour: II. Multiple grooved substrata. Development 108: 635-644.

Dalby MJ, Gadegaard N, Tare R, Andar A, Riehle MO, Herzyk P, Wilkinson CD, Oreffo RO (2007) The control of human mesenchymal cell differentiation using nanoscale symmetry and disorder. Nat Mater 6: 997-1003.

Dan N (2000) Synthesis of hierarchical materials. Trends Biotechnol 18: 370-374.

Davies JE (2003) Understanding peri-implant endosseous healing. J Dent Educ 67: 932-949.

Dugina V, Fontao L, Chaponnier C, Vasiliev J, Gabbiani G (2001) Focal adhesion features during myofibroblastic differentiation are controlled by intracellular and extracellular factors. J Cell Sci 114: 3285-3296.

Dunn G (2000) Cell motility and architecture. In: The Biomedical Engineering Handbook: Second Edition (Bronzino JD, ed), CRC Press LLC, Boca Raton, ch 117.

Dunn GA, Heath JP (1976) A new hypothesis of contact guidance in tissue cells. Exp Cell Res 101: 1-14.

Engel E, Martínez E, Mills CA, Funes M, Planell JA, Samitier J (2009) Mesenchymal stem cell differentiation on microstructured poly (methyl methacrylate) substrates. Ann Anat - Anat Anz 191: 136-144.

Felton R, Imgrund P, Petzoldt F, Friederici V, BusquetsMataix D, Reig L, Amigo V, Calero J (2009) PM companies eye a new future of taking medicine. Metal Powder Rep 64: 12-17. 
Feng D, Marshburn D, Jen D, Weinberg RJ, Taylor RM, Burette A (2007) Stepping into the Third Dimension. J Neurosci 27: 12757-12760.

Haack J, Imgrund P, Hein S, Friederici V, Salk N (2010) The processing of biomaterials for implant applications by Powder Injection Moulding. PIM Int 4: 49-52.

Hallgren C, Reimers H, Chakarov D, Gold J, Wennerberg A (2003) An in vivo study of bone response to implants topographically modified by laser micromachining. Biomaterials 24: 701-710.

Hamilton DW, Brunette DM (2007) The effect of substratum topography on osteoblast adhesion mediated signal transduction and phosphorylation. Biomaterials 28: 1806-1819.

Hamilton DW, Ghrebi S, Kim H, Chehroudi B, Brunette DM (2005) Surface topography and cell behaviour. In: Encyclopedia of Biomaterials and Biomedical Engineering (Bowlin GL, Wnek G, eds), Marcel Dekker, New York, pp $1-11$.

Hamilton D, Wong K, Brunette D (2006) Microfabricated discontinuous-edge surface topographies influence osteoblast adhesion, migration, cytoskeletal organization, and proliferation and enhance matrix and mineral deposition in vitro. Calcif Tissue Int 78: 314-325.

Hamilton DW, Chehroudi B, Brunette DM (2007) Comparative response of epithelial cells and osteoblasts to microfabricated tapered pit topographies in vitro and in vivo. Biomaterials 28: 2281-2293.

Horváth BM, Magyar Z, Zhang Y, Hamburger AW, Bakó L, Visser RG, Bachem CW, Bögre L (2006) EBP1 regulates organ size through cell growth and proliferation in plants. . EMBO J 25: 4909-4920.

Huang H, Ho C, Lee T, Lee T, Liao K, Chen F (2004) Effect of surface roughness of ground titanium on initial cell adhesion. Biomol Eng 21: 93-97.

Imgrund P, Schmidt H, Salk N, Bruinink A, Bitar M (2008) Surface structuring by micro-MIM - Technology and applications. In: Proceedings of the Advances in Powder Metallurgy \& Particulate Materials-2008, Washington DC, pp 230-235.

Jäger M, Zilkens C, Zanger K, Krauspe R (2007) Significance of nano- and microtopography for cell-surface interactions in orthopaedic implants. J Biomed Biotechnol 8: 69036.

Kaiser J-P, Bruinink A (2004) Investigating cellmaterial interactions by monitoring and analysing cell migration. J Mat Sci: Mat in Med 15: 429-435.

Kern P, Veh J, Michler J (2007) New developments in through-mask electrochemical micromachining of titanium. J Micromech Microengin 17: 1168-1177.

Kirmizidis G, Birch MA (2009) Microfabricated grooved substrates influence cell-cell communication and osteoblast differentiation in vitro. Tissue Eng A 15:1 4271436.

Lasagni A, Holzapfel C, Weirich T, Mücklich F (2007) Laser interference metallurgy: A new method for periodic surface microstructure design on multilayered metallic thin films. Appl Surf Sci 253: 8070-8074.

Lee SJ, Choi JS, Park KS, Khang G, Lee YM, Lee HB (2004) Response of MG63 osteoblast-like cells onto polycarbonate membrane surfaces with different micropore sizes. Biomaterials 25: 4699-4707.

Liao H, Andersson AS, Sutherland D, Petronis S, Kasemo B, Thomsen P (2003) Response of rat osteoblastlike cells to microstructured model surfaces in vitro. Biomaterials 24: 649-654.

Lim MW, Burt G, Rutter SV (2005) Use of threedimensional animation for regional anaesthesia teaching: application to interscalene brachial plexus blockade. Br J Anaesth 94: 372-377.

Löfberg J, Ebendal T (1980) Substrate topography and shape of motile cells. Cell Mol Life Sci (CMLS) 36: 508510 .

Lu X, Leng Y (2005) Electrochemical micromachining of titanium surfaces for biomedical applications. J Mat Process Technol 169: 173-178.

McBeath R, Pirone DM, Nelson CM, Bhadriraju K, Chen CS (2004) Cell shape, cytoskeletal tension, and RhoA regulate stem cell lineage commitment. Develop Cell 6: 483-495.

Meyle J, Wolburg H, Von Recum A (1993) Surface micromorphology and cellular interactions. J Biomater Appl 7: 362-374.

Middleton C, Brown A, Brown R, Roberts D (1988) The shape of cultured epithelial cells does not depend on the integrity of their microtubules. J Cell Sci 91: 337-345.

Ohara PT, Buck RC (1979) Contact guidance in vitro. A light, transmission, and scanning electron microscopic study. Exp Cell Res 121: 235-249.

Oron A, Agar G, Oron U, Stein A (2009) Correlation between rate of bony ingrowth to stainless steel, pure titanium, and titanium alloy implants in vivo and formation of hydroxyapetite on their surfaces in vitro. J Biomed Mater Res A 91: 1006-1009.

Puleo DA, Bizios R (1992) Formation of focal contacts by osteoblasts cultured on orthopedic biomaterials. J Biomed Mater Res 26: 291-301.

Puleo DA, Holleran LA, Doremus RH, Bizios R (1991) Osteoblast responses to orthopedic implant materials in vitro. J Biomed Mater Res 25: 711-723.

Santos EAD, Linhares ABR, Rossi AM, Farina M, Soares GA (2005) Effects of surface undulations of biphasic calcium phosphate tablets on human osteoblast behavior. J Biomed Mat Res A 74A: 315-324.

Schneider GB, Zaharias R, Seabold D, Keller J, Stanford C (2004) Differentiation of preosteoblasts is affected by implant surface microtopographies. J Biomed Mater Res 69A: 462-468.

Shouche SP, Rastogi R, Bhagwat SG, Sainis JK (2001) Shape analysis of grains of Indian wheat varieties. Comp Electron Agricult 33: 55-76.

Sutton AJ, Higgins JPT (2008) Recent developments in meta-analysis. Stat Med 27: 625-650.

Weber I (1999) Computer-assisted morphometry of cell-substratum contacts. Croat Med J 40: 334-339.

Webster TJ, Ergun C, Doremus RH, Siegel RW, Bizios R (2000) Specific proteins mediate enhanced osteoblast adhesion on nanophase ceramics. J Biomed Mater Res 51: 475-483.

Woodruff M, Jones P, Farrar D, Grant D, Scotchford C (2007) Human osteoblast cell spreading and vinculin 
expression upon biomaterial surfaces. J Mol Histol 38: 491-499.

Wozniak MA, Modzelewska K, Kwong L, Keely PJ (2004) Focal adhesion regulation of cell behavior. Biochim Biophys Acta Mol Cell Res 1692: 103-119.

Zamir E, Geiger B (2001) Molecular complexity and dynamics of cell-matrix adhesions. J Cell Sci 114: 3583 3590 .

Zhao G, Zinger O, Schwartz Z, Wieland M, Landolt D, Boyan BD (2006) Osteoblast-like cells are sensitive to submicron-scale surface structure. Clin Oral Implants Res 17: 258-264.

Zhao G, Raines A, Wieland M, Schwartz Z, Boyan B (2007) Requirement for both micron- and submicron scale structure for synergistic responses of osteoblasts to substrate surface energy and topography. Biomaterials $\mathbf{2 8}$ : 2821-2829.

\section{Discussion with Reviewers}

Reviewer I: Could you comment on the sole effect of topographic features on the behaviour of cells? In other words, do you expect similar effects on cells as observed here when cells are cultured on other metals, or other material types like polymers and ceramics, with identical surface features?

Authors: Cell reaction to surfaces is cell type dependent and is affected by the micro- and nanoaspects of the surface together with its surface chemistry. As known from several studies using $\mu \mathrm{m}$ sized grooved surfaces the reaction of the adhered cells to microtopography is similar. Surface chemistry seems to play herein a modulatory role. Therefore, we expect that similar effects may be evoked by using other materials which allow cell adhesion. However, this needs to be investigated in greater detail in 